\title{
The effects of service quality and consumer-brand value congruity on hospitality brand loyalty
}

\author{
Rather, R.A \& Camilleri ${ }^{1}$, M.A.
}

This is a pre-publication version.

How to Cite: Rather, R. A. \& Camilleri, M.A. (2019). The effects of service quality and consumerbrand value congruity on hospitality brand loyalty. Anatolia: An International Journal of Tourism and Hospitality Research. https://doi.org/10.1080/13032917.2019.1650289

\begin{abstract}
This research integrates the congruity and the social identity theories to better understand the consumer-brand relationships. A structural equation modelling approach was used to explore the drivers of brand loyalty in the context of upscale hotels. The findings suggest that the customers are increasingly engaging with the brands that reflect their identity and personal values. The consumer-brand value congruity and the hospitality businesses' delivery of high service quality were found to be significant antecedents of consumer-brand identification and engagement. Moreover, we reported that consumer-brand identification is a precursor of consumer-brand engagement and brand loyalty. In conclusion, this contribution implies that luxury hotels ought to satisfy their customers' needs for distinctiveness and self-enhancement whilst exceeding their expectations on service quality.
\end{abstract}

Keywords: branding; service quality; value congruity; consumer-brand engagement; consumerbrand identification; brand loyalty

\footnotetext{
${ }^{1}$ Department of Corporate Communication, Faculty of Media and Knowledge Sciences, University of Malta, Msida, MSD2080, MALTA. Email: mark.a.camilleri@um.edu.mt
} 


\section{Introduction}

The concept of customer brand engagement (CBE) is gaining increased momentum within the hospitality branding literature (King, Sparks, \& Wang, 2016; Leckie, Nyadzayo, \& Johnson, 2016; Rather, Hollebeek, \& Islam, 2019; So, So, King, \& Sparks, 2014). The individual customers' interaction with the brands is characterized by specific levels of cognitive, emotional and behavioral activities (Kumar, Rajan, Gupta, \& Dalla Pozza, 2017; Rather, 2018). Previous empirical research reported that consumer-brand engagement can lead to customer loyalty and increase the profitability for the business (Aaker, Fournier, \& Brasel, 2004; Bowden, 2009; Brodie, Ilic, Juric, \& Hollebeek, 2013; Leckie et al., 2016; Rather, 2019; So, King, Sparks, \& Wang, 2014). Therefore, practitioners are striving in their endeavors to nurture relationships and to develop bonds with consumers (Rather \& Camilleri, 2019). At the same time, they are increasingly communicating their brand identity amongst potential and existing customers (Camilleri, 2018a).

The brand identity can reflect the consumers' aspirations and self-images, personality and values (Rather \& Camilleri, 2019). As a result, the consumers could identify themselves with their favorite brands. They may incorporate brands into their self-concept (Rather, 2018; So, King, Sparks, \& Wang, 2013). Hence, there is scope for different businesses, including upscale hotel brands to establish consumer-brand value congruity in order to instill positive attitudes toward their brand (Kressmann, Sirgy, Herrmann, Huber, Huber, \& Lee, 2006; Sirgy, Lee, Johar, \& Tidwell, 2008; So et al., 2013). This argumentation suggests that there are firm-controlled antecedents, including the delivery of appropriate service quality toward valued consumers (Dhar, 2015; Liat, Mansori, \& Huei, 2014; Mohsin \& Lockyer, 2010). 
The customers often evaluate the functional attributes of service quality "during" and "after" the delivery of the service performance. The service quality is based upon the customer-employee interactions (i.e., the process aspect), the service outcome (i.e., the outcome aspect) and the service environment (Brady \& Cronin, 2001; Dhar, 2015). Therefore, the consumers' perceptions of service quality may usually be based on the comparisons of their service expectations with the actual service performance (Brady \& Cronin, 2001). The consumers continuous evaluations of service quality do not only rely on the outcome of the services they receive; they may also involve their subjective assessment of all intangible aspects of the service delivery, including the service providers' responsiveness and empathy with their consumers ( $\mathrm{He} \& \mathrm{Li}, 2011)$. The delivery of service quality will also have an effect on the customers' preferred contextual self. This concept represents an instrumental driver for the consumers of service-based businesses, including those operating in the hospitality context (Çifci, Ekinci, Whyatt, Japutra, Molinillo, \& Siala, 2016; So et al., 2013).

In the past decades, there was a surge in demand for luxury hotel brands (Han \& Hyun, 2017). Hence, various up-scale hospitality brands were /are increasingly leveraging themselves by offering unique amenities, comforts and service experiences to retain customers. A number of papers in academia have provided several examples of tangible and intangible service quality attributes (e.g. Akbaba, 2006; Han \& Hyun, 2017; Hwang \& Seo, 2016; Rauch, Collins, Nale, \& Barr, 2015). Thus, several hotels have stepped up their commitment to provide commoditized product attributes as they offer comparable service quality that are valued and appreciated by their customers. However, the long-term success of the hospitality brands lies in their ability to convert first-time guests into repeat consumers. Arguably, the satisfied (repeat) guests are more likely to 
engage in word of mouth publicity as they share their reviews and ratings that are read by prospective guests.

This study builds on the extant knowledge in academia. It explores the dimensionality, directionality or strength of the relationships between consumer-brand engagement and / or consumer-brand identification with brand loyalty (Ahn \& Back, 2018; Brodie et al., 2013; Choi \& Kandampully, 2018; Harrigan, Evers, Miles, \& Daly, 2017; Kuenzel \& Halliday, 2008; So et al., 2014; Vivek, Beatty, Dalela, \& Morgan, 2014; Vivek, Beatty, \& Morgan, 2012;). This contribution has three underlying objectives: Firstly, it integrates the academic literature on the congruity and social identity theories as underpinning conceptual bases to explore the service dominant (S-D) logic and the relationship marketing perspectives (Hollebeek, Conduit, \& Brodie, 2016; Rather \& Hollebeek, 2019; Vivek et al., 2014). Secondly, its empirical study investigates the consumerbrand interactions in the context of upscale hotels. We test a research model that comprises service quality and value congruity as antecedents of consumer-brand identification and consumer-brand engagement. We hypothesize that both constructs are mediating factors that anticipate hospitality brand loyalty. In conclusion, we discuss about the research implications for theory and practice. We also identify the limitations of this study and suggest further research avenues.

\section{Literature review}

The consumers' loyalty is characterized by their degree of attachment toward particular brands (Kandampully, Zhang, \& Bilgihan, 2015; Liu, Li, Mizerski \& Soh, 2012). Therefore, it is in the brands' interest to nurture long-term relationships with their key customers (Kandampully et al., 2015). The consumers' repeated purchase (and loyalty) is prompted by their internal dispositions 
(So et al., 2013). Previous literature reported that the brand loyalty rests largely on the consumers' satisfaction as well as on their ongoing evaluations of the service quality and value for money. In a similar vein, the hotel guests continuously assess these factors as they will probably evaluate their service encounters (Rather \& Hollebeek, 2019; So et al., 2017; So et al. 2013). The customers' brand experiences are usually stored in their memory and can have an enduring effect on their satisfaction and loyalty (Brodie et al., 2013). Notwithstanding, the consumers' loyalty toward brands (including upscale hotels) is increasingly being measured in terms of their perceptions of service quality (Hemsley-Brown \& Alnawas, 2016) and value congruity (Su \& Reynolds, 2017). The more the consumers identify themselves with the brands, the more loyal they become (He, $\mathrm{Li}$, \& Harris, 2012). For instance, there are various hospitality firms who are already benefitting from their emotionally engaged customers (Kandampully et al., 2015). Very often, the hotel guests are voluntarily acting as brand ambassadors. The satisfied guests co-create value as they share their experience with other individuals on social media platforms (Buhalis \& Leung, 2018).

\section{Consumer brand identification}

Consumers hold favorable attitudes towards brands if the brands' attributes are consistent with their thoughts (Lee \& Jeong, 2014; Tuškej \& Podnar, 2018). This argument is well pronounced in the self-congruity theory, particularly in the literature on consumer behavior. Consumers use those products and services that are congruent with their personal values (Rather \& Camilleri, 2019; Rather et al., 2019). Moreover, the self-concept explains the individuals' beliefs about their identities, lifestyles, and preferences. Consequentially, the consumers will often choose those products and services that represent their preferred (ideal self) and/or their perceived image (Han 
\& Hyun, 2017). Consumers purchase goods and services to express their own self, and / or to fulfil their psychological needs whist satisfying their utilitarian benefits (Tuškej et al., 2013).

Therefore, the role of value congruity lies in the delivery of the distinctive brand images that are ultimately intended to entice customers to purchase products; and to become loyal to the brand (Liu et al., 2012). Consumers may be attracted toward those brands that enable them to maintain and express their sense of self more fully and authentically (Bhattacharya \& Sen, 2003). Hence, there is scope for businesses and brands to establish high self-congruity in order to enhance the consumers' positive attitudes toward their offerings (Sirgy et al., 2008). Some previous studies have already confirmed that the self-congruity construct has a positive impact on brand loyalty (Kressman et al., 2006, Sirgy et al., 2008), as consumers identify themselves with the companies' symbols and social cues (Bhattacharya \& Sen, 2003; Homburg, Wieseke, \& Hoyer, 2009). This happens because the brands' values are consistent with the consumers' expectations (Lee \& Jeong, 2014). Consumers often compare the similarity or dissimilarity of the brands' values with their own set of values, as they evolve, fluctuate, and change over time (So et al., 2013).

Previous research on consumer-brand identification demonstrated that consumers are attracted to those brands that share the same self-definitional attributes (So, King, Hudson, \& Meng, 2017; Kuenzel \& Halliday 2008). For this reason, this construct is a powerful predictor of consumer behaviors such as repurchase intention and word-of-mouth as the individuals perceive that the brand reflects their values (Bhattacharya \& Sen, 2003; Romero, 2017). This argumentation is also relevant for upscale hotel brands. Therefore, consumer-brand identification is an important, yet underutilized construct in the hospitality journals. Recently, a few researchers reported that hotel 
guests can identify themselves with their favorite hospitality brand (Rather \& Camilleri, 2019; So et al., 2017). Hence, the customers' identification with particular hotel brands can have an effect on their engagement and loyalty with them. This leads to the following hypotheses:

\section{H1: The consumer-brand identification positively influences hotel brand loyalty.}

\section{H2: The consumer-brand identification positively influences consumer-brand engagement.}

\section{Consumer-brand engagement}

Savvy businesses are increasingly appreciating the importance of retaining value-generating customers (Hollebeck, 2011; Kandampully et al., 2015). Many firms are investing their resources to forge strong relationships with profitable customers to garner their loyalty (Leckie et al., 2016). As a result, consumers are interacting and co-creating experiences following their brand engagement (Aaker et al., 2004; Brodie et al., 2013; Rather et al., 2019; Rihova, Buhalis, Moital, \& Gouthro, 2015; Romero, 2017). Bowden (2009) held that the customer experience is a precursor of customer-engagement. Other researchers contended that there are behavioral, emotional, and cognitive facets of consumer-brand engagement (Ahn \& Back, 2018; Harrigan et al., 2017; Vivek et al., 2014). The customers' 'behavioral' activity is expressed through their interaction with the brand (Hollebeek, 2011). The 'emotional' feature represents the consumers' inspiration and/or pride; whilst the brand-related 'cognitive' aspect involves the consumers' level of concentration and/or engrossment.

Therefore, aspirational and social-engagement dimensions ought to be incorporated when exploring the customers' interactions with particular brands (Brakus, Schmitt, \& Zarantello, 2009). When consumers become engaged with their preferred brands, they tend to exhibit stronger convictions toward them. (Bowden, 2009). Vivek et al. (2014) maintained that consumer-brand 
engagement involves enthused participation, conscious attention and social connections between the consumers and their service-providers. Relevant theoretical underpinnings also acknowledge the benefits of customer engagement in tourism and hospitality (Rather et al., 2019; So et al., 2014). However, currently there is scant empirical research that has explored the customer engagement, cocreation and word of mouth in luxury hotel settings. For instance, hotel guests can share their experiences with other prospects, usually in the form of qualitative reviews or quantitative ratings via TripAdvisor or Yelp (Camilleri, 2018a, b). Similarly, booking engines, including Booking.com and Expedia, among others, are also publishing the consumers' recommendations to online users, on their web sites.

Very often, hospitality brands are encouraging their consumers to interact with them and with other individuals, as engaged customers will probably draw prospective customers (Buhalis \& Leung, 2018). The customer-brand engagement is evidenced when online users' read the consumer reviews on the digital media (Camilleri, 2019c; So et al., 2017). Alternatively, individuals may hear about the service experiences directly from the extant customers (Kozak \& Kozak, 2018). It is very likely that prospective customers will rely on the advice and recommendations of past customers. Hence, service brands, including luxury hotels ought to engage with their guests to improve the likelihood that they receive positive word of mouth publicity from them (So et al., 2017; Kandampully et al., 2015). They need to exceed their expectations to build their loyalty and turn them into brand advocates. This leads to our third hypothesis:

\section{H3: The consumer-brand engagement positively influences hotel brand loyalty}




\section{Perceived service quality}

The perceived service delivery differs from producer to producer, from customer to customer, and from day to day. For instance, service staff may not always be capable of delivering technical and functional quality (Grönroos, 1984; Liao \& Chuang, 2004; Mohsin \& Lockyer, 2010). However, the customers will continuously evaluate the service quality during their interactions with the business. They may assess quality on (i) the physical aspects that focus on the technical and functional quality of the service product; (ii) the corporate image or profile; and on (iii) the interaction between the service employees and their customers. Parasuraman, Zeithaml and Berry (1988)'s SERVQUAL dimensions measured the employees' (i) reliability (i.e. capability to deliver the services); (ii) assurance (i.e. ability to inspire confidence among customers); (iii) empathy (i.e. sensibility towards the customers' feelings); (iv) responsiveness (i.e. prompt positive reactions) and (v) tangibles (i.e. the appearance of the physical facilities, personnel and communication materials). The concepts of interactivity, rapport and value co-creation are highly relevant within the tourism and hospitality contexts; as the delivery of service is often characterized by the human relationships (Rihova et al., 2015). This argumentation about perceived service quality can be associated with the consumer-brand engagement construct ( $\mathrm{He} \& \mathrm{Li}, 2011)$. As a matter of fact, several empirical studies reported that quality constructs were often considered as motivational antecedents to consumer-brand engagement (Harmeling, Moffett, Arnold, \& Carlson, 2017).

Consumers are increasingly demanding higher quality during the delivery of service (Akbaba, 2006; He \& Li, 2011; Hemsley-Brown \& Alnawas, 2016; Hui, Wan, \& Ho, 2007; Mohsin \& Lockyer, 2010). They are continuously comparing their expectations with the service providers' actual performance (Cronin \& Taylor, 1992). Hence, the service quality comprises the process as 
well as the outcome of the service delivery. Hence, the evaluation of service quality is based upon the customer-employee interaction (i.e., the process aspect), the service environment, and the service outcome (Brady \& Cronin, 2001). Relevant literature suggests the delivery of service quality is crucial to retaining customers in an increasingly competitive hospitality industry. Therefore, it is often monitored to improve the loyalty of customers (Camilleri, 2018a). A superior service quality can foster positive influences in the hospitality context, including; customer satisfaction and corporate image, and can ultimately lead to consumer retention $(\mathrm{Hu}$, Kandampully \& Juwaheer, 2009; Mohsin \& Lockyer, 2010). Conversely, the hotel businesses that are not delivering appropriate service quality may face contentious issues such as negative customer satisfaction (Akbaba, 2006; Dedeoğlu \& Demirer 2015) that is often communicated via online reviews. Hence, hotel managers ought to understand the tangible and intangible attributes that must be improved in order to enhance their guests' satisfaction at all service levels (Rauch et al., 2015).

The hospitality literature has often reported that the hotels' services, location, cleanliness, price, security and the friendliness of the staff as important aspects of service quality (Rauch et al., 2015). Akbaba (2006) identified some of the attributes that may complicate the hotels' task of defining, delivering and measuring service quality. He suggested that the demand for service quality is generally clustered around peak periods of the day, week or year, such as; check-in and check-out times. These times may prove to be the moments of truth for the hospitality brands as hotel businesses are expected to deliver consistent service quality to their guests. Moreover, a few studies indicated that customers will opt to stay with particular hotel brands if they exceed their service expectations. Hence, the satisfied consumers will be loyal to those hospitality brands that 
deliver service quality (Dedeoğlu \& Demirer, 2015; Rauch et al., 2015; So et al., 2013). This leads to the following hypotheses:

H4: The perceived service quality positively influences consumer-brand engagement H5: The perceived service quality positively influences consumer-brand identification H5a: The consumer-brand engagement mediates the relationship between service quality and hotel brand loyalty

H5b: The consumer-brand identification mediates the relationship between service quality and consumer-brand engagement

\section{The consumer-brand value congruity}

A pertinent review suggests that consumer-brand identification is a mediator between customerbrand value congruence and brand loyalty (Elbedweihy, Jayawardhena, Elsharnouby, \& Elsharnouby, 2016). The value congruity construct suggests that the delivery of value-added services is a key component for successful brands, particularly due to their heterogeneity characteristics (Lee \& Jeong, 2014; Zeithaml, Bolton, Deighton, Keiningham, Lemon, \& Petersen, 2006). Therefore, the congruity (i.e. when there is a perceived fit) between the customers' and the brands' values can lead to favorable psychological outcomes (e.g. trust, satisfaction and positive behavioral intentions, etc.) (Lee \& Jeong, 2014; Zhang \& Bloemer, 2008). Therefore, the consumers' identification with the distinctive brands and their offerings is likely to be driven by the brands' personalities (Rather \& Camilleri, 2019). Several researchers in the branding domain have noted such perceived congruity between the brands and their consumers' personalities (Lam, Ahearne, Mullins, Hayati, \& Schillewaert, 2013; Su \& Reynolds, 2017). 
For instance, Su and Reynolds (2017) reported that the hotels' personality dimensions may position or strengthen their respective brands as they translate to symbolic meanings for their guests. They argued that both the consumers' perceived self-image congruity as well as their functional congruity with the brand have determined their attitudes towards it. Yet, they went on to suggest that the functional congruity had a greater effect than self-image congruity. Hence, their study indicated that the business consumers appreciated the hotels' functional value (as opposed to the leisure travelers who valued the hotels' congruity with their self-image). Other studies also found that consumers prefer to use products and services that represent their personal values (Rather, 2018; Homburg et al., 2009). These contributions posited that when consumers identify themselves with their favorite brands, they are more likely to be satisfied with their service, and may therefore remain loyal to them (Lee \& Jeong, 2014; Zhang \& Bloemer, 2008). They will probably interact with those brands that enable them to realize their own self-concept. Therefore, when the brands' values are congruent with their customers' values; it is very likely that there is increased consumer-brand engagement and identification (Bhattacharya \& Sen, 2003; Rather, 2018; So et al., 2017). This leads to the last hypotheses.

H6: The consumer-brand value congruity positively influences consumer-brand identification. H7: The consumer-brand value congruity positively influences consumer-brand engagement. H7a: The consumer-brand identification mediates the relationship between consumer-brand value congruity and engagement.

H7b: The consumer-brand identification mediates the relationship between consumer-brand value congruity and hotel brand loyalty 


\section{The proposed conceptual model}

Figure 1 features the research model of this empirical investigation. We hypothesize that perceived service quality and consumer-brand value congruity are both antecedents of consumer-brand engagement and consumer-brand identification. Moreover, the latter two constructs are the precursors of brand loyalty.

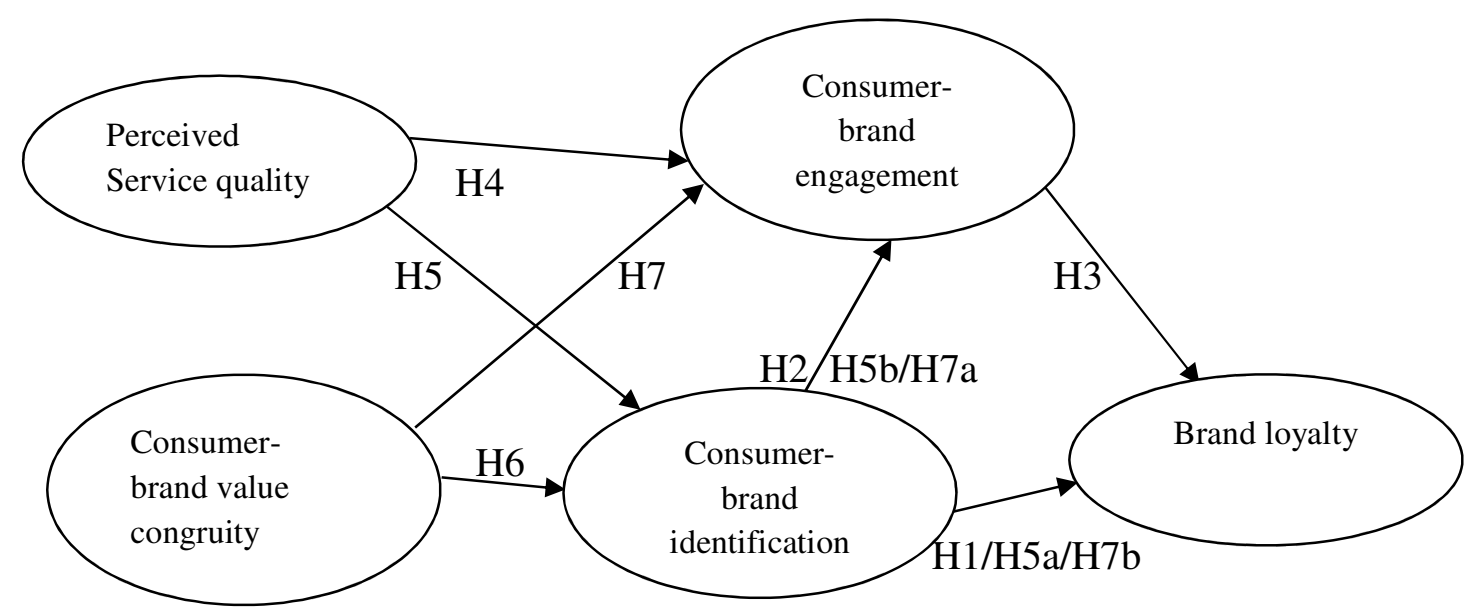

Figure 1: The conceptual model of this study

\section{Methodology}

The data was collected from upscale hospitality properties located in six Indian cities, including; Srinagar, Gulmarg, Phalgam, Jammu, Katra and Amritsar. The questionnaires were distributed in summer 2018 to the hotel guests by the reception employees, at different times of the day, over a five-week period. There was a total of 410 respondents out of 2450 targeted participants who have voluntarily chosen to take part in this research. This sample represented a usable response rate of $17 \%$ of all targeted respondents. The surveyed participants disclosed their socio-demographic 
details in the latter part of the survey questionnaire. However, the participants' identity remained anonymous. Their responses remained confidential and there was no way that any individual participant could be identified. The survey instrument was structured in a way where the dependent and independent constructs were placed in different parts of the questionnaire.

All constructs in this research were valid and reliable measures that have been previously tried and tested in academia. The survey questionnaire has consistently adopted a 5-point Likert scaling mechanism, where the responses ranged from; $1=$ strongly disagree to $5=$ strongly agree, and 3 signaled an indecision. The consumer-brand engagement scale consisted of 8 items that were adapted from Vivek et al.'s (2014) study. This measure included dimensions that explored the respondents' enthused participation, conscious attention and social connection with the hotel brand.

The researchers have utilized He and Li's (2011) 3-items that measured the participants' perceptions on the hotels' service quality. The consumer-brand value-congruity construct consisted of 3-items that were drawn from Tuškej et al., 2013. Moreover, there were 4-items that measured the hotel guests' brand identification (Tuskej \& Podnar, 2018), and another 4-items that explored their loyalty towards the hotel brand (So et al., 2014). Several steps were undertaken to avoid the common method bias that is associated with the surveys' measures. We relied on Harman's single-factor test to check for "systematic error variances" among variables as correlations may be affected by common method variance as a function of both the method and the particular constructs being measured. 


\section{Results}

A descriptive analysis of the respondents indicates that $55 \%(n=226)$ were male while $45 \%$ $(n=185)$ were female. The majority of the respondents $(65 \%)$ were between 31 and 50 years of age $(n=152)$. Most of them had pursued higher education (as they completed undergraduate and postgraduate degrees). Moreover, a third of the respondents indicated that they were repeat (loyal) customers.

\section{The Confirmatory Factor Analysis (CFA)}

We employed a comprehensive, two-step structural equation modelling approach including a confirmatory factor analysis (CFA) to verify the validity and reliability of our chosen measures (Anderson \& Gerbing, 1988). AMOS 20.0 SEM software was used to test our research model.

The measurement model that was used in this study comprised five constructs: perceived service quality, consumer-brand value congruity, consumer-brand engagement, consumer-brand identification and brand loyalty. Generally, the respondents indicated that they agreed with the survey items as the mean scores were close to 5. Moreover, the standard deviations indicated that there was a narrow spread of participants' responses, ranging from 0.41 to 1.46 , indicating a narrow spread around the mean.

The CFA results suggest that the standard factor loadings for all items were greater than 0.70 . The findings reported high square multiple correlations (SMC), as reported in Table 1. 
Table 1 The Descriptive Statistics, Standard Factor Loadings and Square Multiple Correlations for each variable.

\begin{tabular}{|c|c|c|c|c|c|}
\hline \multicolumn{2}{|c|}{ Construct and Items } & \multirow{2}{*}{\begin{tabular}{|c|} 
SL \\
ation)
\end{tabular}} & \multirow[t]{2}{*}{$\mathbf{M}$} & \multirow[t]{2}{*}{ SD } & \multirow{2}{*}{ SMC } \\
\hline \multicolumn{2}{|r|}{ Customer Brand Engagement (Conscious Attention) } & & & & \\
\hline CA1 & Anything related to this hotel brand site grabs my attention & 0.91 & 4.28 & 1.23 & 0.82 \\
\hline CA2 & I pay a lot of attention to anything about this hotel brand & 0.88 & 4.08 & 1.08 & 0.84 \\
\hline CA3 & I like to learn more about this hotel brand & 0.92 & 4.22 & 1.21 & 0.69 \\
\hline \multicolumn{6}{|c|}{ Customer Brand Engagement (Enthused Participation) } \\
\hline EP1 & I spend a lot of my discretionary time in this hotel brand & 0.82 & 4.78 & 1.01 & 0.87 \\
\hline EP2 & I am passionate about this hotel brand & 0.92 & 4.19 & 1.22 & 0.85 \\
\hline EP3 & My days would not be the same without this hotel brand & 0.89 & 4.06 & 1.16 & 0.76 \\
\hline \multicolumn{6}{|c|}{ Customer Brand Engagement (Social Connection) } \\
\hline SC1 & I enjoy this hotel brand more when I am with others & 0.93 & 4.66 & 1.08 & 0.83 \\
\hline $\mathrm{SC} 2$ & I love this hotel brand with my friends & 0.81 & 4.3 & 1.20 & 0.85 \\
\hline \multicolumn{6}{|c|}{ Brand loyalty } \\
\hline BL1 & If available, I will stay with this hotel brand the next time I travel & 0.85 & 4.55 & 1.3 & 0.72 \\
\hline BL2 & I intend to keep staying with this hotel brand & 0.78 & 4.61 & 1.22 & 0.61 \\
\hline BL3 & I am committed to this hotel brand & 0.93 & 4.15 & 1.14 & 0.87 \\
\hline BL4 & $\begin{array}{l}\text { I would be willing to pay a higher price for this hotel brand over } \\
\text { other brands }\end{array}$ & 0.92 & 4.24 & 1.10 & 0.85 \\
\hline \multicolumn{6}{|c|}{ Customer Brand Identification } \\
\hline CBI1 & This hotel brand a reflects who I am & 0.81 & 3.09 & 1.46 & 0.64 \\
\hline CBI2 & This hotel brand embodies my personal beliefs & 0.86 & 3.98 & 1.42 & 0.73 \\
\hline $\mathrm{CBI} 3$ & I have a lot in common with other people using this hotel brand & 0.90 & 4.18 & 1.32 & 0.81 \\
\hline CBI4 & This hotel brand embodies beliefs that I share with other people & 0.85 & 4.82 & 1.11 & 0.71 \\
\hline \multicolumn{6}{|c|}{ Customer- Brand Value Congruity } \\
\hline $\mathrm{VC1}$ & $\begin{array}{l}\text { I have a clear understanding of the core values of this hotel } \\
\text { brand }\end{array}$ & 0.98 & 4.42 & 1.04 & 0.87 \\
\hline $\mathrm{VC} 2$ & I really support the intent of the core values of this hotel brand & 0.97 & 4.46 & 1.01 & 0.88 \\
\hline VC3 & $\begin{array}{l}\text { I have a great deal of agreement about what this hotel brand's } \\
\text { core values represent }\end{array}$ & 0.73 & 4.87 & 0.41 & 0.53 \\
\hline \multicolumn{6}{|c|}{ Perceived Service Quality } \\
\hline SQ1 & The hotel provider deliver excellent overall service & 0.85 & 4.97 & 1.43 & 0.79 \\
\hline SQ2 & The offerings of the hotel are of high quality & 0.92 & 3.78 & 1.34 & 0.74 \\
\hline SQ3 & The hotel provider deliver superior service in every way & 0.73 & 3.55 & 1.23 & 0.81 \\
\hline
\end{tabular}

Note: $\mathrm{SD}=$ standard deviation, $\mathrm{M}=$ mean, $\mathrm{SL}=$ standard loadings, $\mathrm{SMC}=$ squared multiple correlation. 


\section{Validity and reliability}

Both convergent and discriminant validity were examined to substantiate the validity of our study. The convergent validity of the formative indicators was inspected by using redundancy analysis. The discriminant validity was examined by relating the square root of each construct's average variance extracted (AVE) with the off-diagonal correlations. The AVE values were above 0.8, much higher than Fornell and Larcker's (1981) recommendations. The composite reliability and internal consistency have exceeded the threshold value of 0.7 as they were greater than 0.9 . Table 2 presents the results of the reliability and validity of the chosen measures.

Table 2 The Validity and Reliability of the Construct

\begin{tabular}{lccccccccc} 
Construct & Items & a & CR & AVE & 1 & 2 & 3 & 4 & 5 \\
\hline 1. CBE & 8 & 0.92 & 0.943 & 0.832 & $\mathbf{0 . 8 8 4}$ & & & & \\
2. BL & 4 & 0.95 & 0.951 & 0.765 & 0.732 & $\mathbf{0 . 8 7 3}$ & & & \\
3. CBI & 4 & 0.91 & 0.914 & 0.728 & 0.742 & 0.761 & $\mathbf{0 . 8 4 5}$ & & \\
4. VC & 3 & 0.92 & 0.944 & 0.810 & 0.713 & 0.720 & 0.822 & $\mathbf{0 . 8 7 7}$ & \\
5. SQ & 3 & 0.92 & 0.931 & 0.745 & 0.822 & 0.743 & 0.734 & 0.832 & 0.891 \\
\hline
\end{tabular}

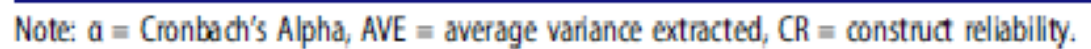

Off diagonal factors are correlations and bold diagonal factors are square root of variance shared.

\section{Assessment of the structural model}

The overall structural model fit indices obtained: $\chi 2=607.208, \mathrm{df}=197, \chi 2 / \mathrm{df}=3.82, \mathrm{TLI}=.94$, $\mathrm{CFI}=.96, \mathrm{NFI}=.94, \mathrm{GFI}=.87, \mathrm{RMSEA}=.078$, and $\mathrm{SRMR}=.062$ indicated satisfactory model fit. This study established the significant impact of perceived service quality on consumer-brand engagement $(\beta=.41, \mathrm{t}=9.40, \mathrm{p}<.001)$, followed by consumer-brand identification $(\beta=.39, \mathrm{t}=$ 7.13, $\mathrm{p}<.001$ ), therefore $\mathrm{H} 4$ and $\mathrm{H} 5$ were supported. The present research established significant 
and high impact of value congruity on consumer-brand identification $(\beta=.67, \mathrm{t}=13.67, \mathrm{p}<.001)$, followed by consumer-brand engagement $(\beta=.35, \mathrm{t}=7.47, \mathrm{p}<.001)$ thereby supporting $\mathrm{H} 6$ and $\mathrm{H} 7 . \mathrm{H} 1$ and $\mathrm{H} 2$ were conducted to investigate the impact of consumer-brand engagement on brand loyalty $(\beta=.27, \mathrm{t}=4.83, \mathrm{p}<.001)$ and of consumer-brand identification on consumer-brand engagement $(\beta=.57, \mathrm{t}=10.89, \mathrm{p}<.001) . \mathrm{H} 3$ was conducted to explore the influence of consumerbrand engagement on brand loyalty $(\beta=.45, \mathrm{t}=6.47, \mathrm{p}<.001)$. The findings from Table 3 suggest that there are positive and highly significant relationships in this structured model. Table 4 explains how consumer-brand identification mediated the effects between perceived service quality and brand loyalty, and between perceived service quality and consumer-brand engagement.

Table 3 Structural Equation Modelling Results

$\begin{array}{lllll}\text { Hypotheses } & \text { Relationships } & \boldsymbol{\beta} & \mathbf{R}^{2} & \text { T-value } \\ \text { H1 } & \mathrm{CBI} \rightarrow \mathrm{BL} & 0.27 * * * & 0.78 & 4.83 \\ \mathrm{H} 2 & \mathrm{CBI} \rightarrow \mathrm{CBE} & 0.57 * * & 0.71 & 10.89 \\ \mathrm{H} 3 & \mathrm{CBE} \rightarrow \mathrm{BL} & 0.45^{* *} & 0.78 & 6.47 \\ \mathrm{H} 4 & \mathrm{SQ} \rightarrow \mathrm{CBE} & 0.41^{* * *} & 0.71 & 9.40 \\ \mathrm{H} 5 & \mathrm{SQ} \rightarrow \mathrm{CBI} & 0.39^{* *} & 0.45 & 7.13 \\ \mathrm{H} 6 & \mathrm{VC} \rightarrow \mathrm{CBI} & 0.67 * * * & 0.45 & 13.67 \\ \mathrm{H} 7 & \mathrm{VC} \rightarrow \mathrm{CBE} & 0.35^{* * *} & 0.71 & 7.47 \\ \text { Note: }{ }^{*}=0.05,{ }^{* *}=0.01,{ }^{* * *} 0.001, \mathrm{PM}=\text { partial } & \end{array}$

Table 4 Mediation Analysis

\begin{tabular}{lllllcl} 
Hypotheses & Relationship & \multicolumn{2}{l}{ Direct Indirect } & Total & Mediation & Sobel Test \\
H5a: & $\mathrm{SQ} \rightarrow \mathrm{CBI} \rightarrow \mathrm{BL}$ & 0.45 & 0.35 & 0.80 & $\mathrm{PM}$ & 10.34 \\
H5b: & $\mathrm{SQ} \rightarrow \mathrm{CBI} \rightarrow \mathrm{CBE}$ & 0.39 & 0.33 & 0.72 & $\mathrm{PM}$ & 8.39 \\
H7a: & $\mathrm{VC} \rightarrow \mathrm{CBI} \rightarrow \mathrm{CBE}$ & 0.38 & 0.33 & 0.71 & $\mathrm{PM}$ & 7.40 \\
H7b: & $\mathrm{VC} \rightarrow \mathrm{CBI} \rightarrow \mathrm{BL}$ & 0.50 & 0.31 & 0.81 & $\mathrm{PM}$ & 11.45
\end{tabular}




\section{Conclusion and implications}

This contribution adds value to our extant academic knowledge as it integrated the service dominant logic with the social identity and congruity theories. The empirical study has shed light on the direct and indirect effects of service quality and consumer-brand value congruity on consumer-brand identification, consumer-brand engagement and brand loyalty. Therefore, this paper's empirical framework has validated previously tried and tested measures to explore the customers' perceptions on the drivers and consequences of consumer-brand identification and engagement.

This study has proved that the combined effects of value congruity and service quality can have an impact on consumer-brand identification and engagement. The results from this study indicated that the consumer-brand identification as well as consumer-brand engagement were predicting the consumers' loyalty toward the brand. The findings also reported that consumer-brand identification, perceived service quality as well as value congruity were significant antecedents of consumer-brand engagement. In addition, the service quality and value congruity had moderate, direct effects on consumer brand identification. Furthermore, the empirical results revealed that consumer brand identification has mediated the relationships between value congruity and brand loyalty, and between service quality and brand loyalty.

In a similar vein, a critical analysis of the relevant literature revealed that consumer-brand relationships are dependent on the customers' identification with their favorite brands (Çifci et al., 2016; Rather \& Camilleri, 2019; Rather, 2018; Tuskej \& Podnar, 2018; So et al., 2013; 2014). Specifically, the consumer-brand identification is related with the consumer-brand value congruity 
(Rather, 2018). As a matter of fact, past research also reported that consumer-brand identification has a positive effect on customer behaviors and attitudes (in terms of loyalty and commitment) (Rather \& Camilleri, 2019). However, in this case, the findings of this study suggest that both the consumer-brand value congruity and perceived service quality are the significant antecedents of consumer-brand identification and engagement.

The consumer-brand identification will inevitably trigger supporting behaviors like increased purchase / repurchase intentions (e.g., Kuenzel \& Halliday, 2008) or positive word-of-mouth recommendations (Tuskej et al., 2013), among other positive outcomes. Therefore, hospitality practitioners ought to nurture physical and virtual relationships with their stakeholders via a multitude of approaches, if they want them to remain loyal to their business (Dedeoğlu \& Demirer, 2015). Public activities such as sponsorship, charity events, social campaigns and so on can be used to enhance the brands' image among interested parties, including customers (Bhattacharya \& Sen, 2003). For this reason, several hospitality brands are increasingly engaging in interactive communications either individually or in groups, via digital technologies, including social media, blogs, v-blogs, video clips, review sites, etc. (Camilleri, 2018a; So et al., 2017; Su, Mariadoss, \& Reynolds, 2015). Very often, individuals are intrigued to share their travel experiences, including their hotel accommodation (Camilleri, 2018b).

In a nutshell, this contribution posited that the hotel guests will probably engage and remain loyal to particular hospitality brands if they feel and perceive that their values reflect their own values. This study reported that the consumer-brand value congruity had a very significant effect on the consumers' identification and engagement with the upscale hospitality brands. It indicated that the 
hotel guests who have experienced excellent service quality are more likely to share their experience with other individuals. Hence, hospitality managers need to ensure that their brand consistently delivers high levels of tangible and intangible service quality (at all times) to their valued guests in order to create long-lasting relationships with them. The hotels' provision of the service quality and brand experience ought to meet and exceed their guests' expectations to satisfy their self-enhancement needs and their sense of well-being.

Future studies can surely complement this contribution in a number of ways: There is scope for other research to replicate the findings of this paper. Other empirical studies could broaden our analysis by incorporating additional relational constructs into new research models, including cocreation, customer desire, customer involvement, subjective well-being, brand prestige, customer experience, satisfaction, self-brand connection, among others. A longitudinal study in consumerbrand interactions could delve deeper into the dynamic nature of consumer-brand value congruity, to establish its effects on brand loyalty in the long run. Future research can also investigate the relevance of continuous interactive engagements with consumers via online conversations. Further knowledge about these aspects could inform and guide the hospitality practitioners to improve the consumers' loyalty towards their brand.

\section{Acknowledgements}

We express our gratitude to the hotels that allowed us to access their organisations. The warmth and openness with which we were received was a clear reflection of their hospitality ethos. We cannot name specific hotels, but they all deserve our sincere thanks. We also thank the research participants (hotel guests) who have voluntarily taken part in this study. Moreover, we are grateful to this journal editor and his reviewers for their constructive remarks and suggestions. 


\section{ORCID}

Raouf Ahmad Rather http://orcid.org/0000-0002-9242-1165

Mark Anthony Camilleri https://orcid.org/0000-0003-1288-4256

\section{References}

Aaker, J., Fournier, S., \& Brasel, S. A. (2004). When good brands do bad. Journal of Consumer research, 31(1), 1-16.

Ahn, J., \& Back, K. J. (2018). Influence of brand relationship on customer attitude toward integrated resort brands: a cognitive, affective, and conative perspective. Journal of Travel \& Tourism Marketing, 35(4), 449-460.

Akbaba, A. (2006). Measuring service quality in the hotel industry: A study in a business hotel in Turkey. International Journal of Hospitality Management, 25(2), 170-192.

Anderson, J. C., \& Gerbing, D. W. (1988). Structural equation modelling in practice: A review and recommended two-step approach. Psychological Bulletin, 103(3), 411-423.

Bhattacharya, C. B., \& Sen, S. (2003). Consumer company identification: A framework for understanding consumers' relationships with companies. Journal of Marketing, 67(2), 76-88.

Bowden, J.L.H. 2009. The process of customer engagement: A conceptual framework. Journal of Marketing Theory and Practice, 17(1), 63-74.

Brady, M. K., \& Cronin Jr, J. J. (2001). Some new thoughts on conceptualizing perceived service quality: a hierarchical approach. Journal of Marketing, 65(3), 34-49.

Brakus, J.J., Schmitt, B.H. and Zarantello, L. 2009. Brand experience: What is it? How is it measured? Does it affect loyalty? Journal of Marketing, 73(3), 52-68

Brodie, R. J., Ilic, A., Juric, B., \& Hollebeek, L. (2013). Consumer engagement in a virtual brand community: An exploratory analysis. Journal of Business Research, 66(1), 105-114.

Buhalis, D., \& Leung, R. (2018). Smart hospitality-Interconnectivity and interoperability towards an ecosystem. International Journal of Hospitality Management, 71, 41-50.

Camilleri, M. A. (2018a). The SMEs' technology acceptance of digital media for stakeholder engagement. Journal of Small Business and Enterprise Development. [online]. Retrieved from https://www.emerald.com/insight/content/doi/10.1108/JSBED-02-2018-0042/full/html Vol. Issue No. pp. 
Camilleri, M. A. (2018b). Travel marketing, tourism economics and the airline product. An introduction to theory and practice. Cham, Switzerland: Springer.

Camilleri, M. A. (2018c). The promotion of responsible tourism management through digital media. Tourism Planning \& Development, 15(6), 653-671.

Choi, H., \& Kandampully, J. (2018). The effect of atmosphere on customer engagement in upscale hotels: An application of SOR paradigm. International Journal of Hospitality Management, 77, 40-50.

Çifci, S., Ekinci, Y., Whyatt, G., Japutra, A., Molinillo, S., \& Siala, H. (2016). A cross validation of Consumer-Based Brand Equity models: Driving customer equity in retail brands. Journal of Business Research, 69(9), 3740-3747.

Cronin Jr, J. J., \& Taylor, S. A. (1992). Measuring service quality: A reexamination and extension. Journal of Marketing, 56(3), 55-68.

Dedeoğlu, B. B., \& Demirer, H. (2015). Differences in service quality perceptions of stakeholders in the hotel industry. International Journal of Contemporary Hospitality Management, 27(1), 130146.

Dhar, R. L. (2015). Service quality and the training of employees: The mediating role of organizational commitment. Tourism Management, 46, 419-430.

Elbedweihy, A., Jayawardhena, C., Elsharnouby, M. H., \& Elsharnouby, T. H. (2016). Customer relationship building: The role of brand attractiveness and consumer-brand identification. Journal of Business Research, 69, 2901-2910.

Fornell, C., \& Larcker, D. F. (1981). Evaluating structural equation models with unobservable variables and measurement error. Journal of Marketing Research, 18(1), 39-50.

Grönroos, C. (1984). A service quality model and its marketing implications. European Journal of Marketing, 18(4), 36-44.

Han, H., \& Hyun, S. S. (2017). Impact of hotel-restaurant image and quality of physicalenvironment, service, and food on satisfaction and intention. International Journal of Hospitality Management, 63, 82-92.

Harmeling, C. M., Moffett, J. W., Arnold, M. J., \& Carlson, B. D. (2017). Toward a theory of customer engagement marketing. Journal of the Academy of Marketing Science, 45(3), 312-335.

Harrigan, P., Evers, U., Miles, M., \& Daly, T. (2017). Customer engagement with tourism social media brands. Tourism Management, 59, 597-609.

Hartline, M. D., \& Jones, K. C. (1996). Employee performance cues in a hotel service environment: Influence on perceived service quality, value, and word-of-mouth intentions. Journal of Business Research, 35(3), 207-215. 
He, H., \& Li, Y. (2011). CSR and service brand: The mediating effect of brand identification and moderating effect of service quality. Journal of Business Ethics, 100(4), 673-688.

He, H., Li, Y., \& Harris, L. (2012). Social identity perspective on brand loyalty. Journal of Business Research, 65(5), 648-657.

Hemsley-Brown, J., \& Alnawas, I. (2016). Service quality and brand loyalty: The mediation effect of brand passion, brand affection and self-brand connection. International Journal of Contemporary Hospitality Management, 28(12), 2771-2794

Hollebeek, L. (2011). Exploring customer brand engagement: definition and themes. Journal of Strategic Marketing, 19(7), 555-573.

Hollebeek, L. D., Conduit, J., \& Brodie, R. J. (2016). Strategic drivers, anticipated \& unanticipated outcomes of customer engagement, Journal of Marketing Management, 32(5-6), 393-398.

Homburg, C., Wieseke, J., \& Hoyer, W. D. (2009). Social identity and the service-profit chain. Journal of Marketing, 73(2), 38-54.

Hui, T. K., Wan, D., \& Ho, A. (2007). Tourists' satisfaction, recommendation and revisiting Singapore. Tourism Management, 28(4), 965-975.

Hwang, J., \& Seo, S. (2016). A critical review of research on customer experience management: Theoretical, methodological and cultural perspectives. International Journal of Contemporary Hospitality Management, 28(10), 2218-2246.

Kandampully, J., Zhang, T., \& Bilgihan, A. (2015). Customer loyalty: A review and future directions with a special focus on the hospitality industry. International Journal of Contemporary Hospitality Management, 27(3), 379-414.

Kandampully, J., Zhang, T., \& Jaakkola, E. (2018). Customer experience management in hospitality: A literature synthesis, new understanding and research agenda. International Journal of Contemporary Hospitality Management, 30(1), 21-56.

Kozak, M., \& Kozak, N. (2018, eds.). Tourist behavior: An experiential perspective. Cham, Switzerland: Springer.

Kressmann, F., Sirgy, M. J., Herrmann, A., Huber, F., Huber, S., \& Lee, D. J. (2006). Direct and indirect effects of self-image congruence on brand loyalty. Journal of Business Research, 59(9), 955-964. Doi:10.1016/j.jbusres.2006.06.001

Kuenzel, S., \& Halliday, S.V. (2008). Investigating antecedents and consequences of brand identification. Journal of Product and Brand Management, 17, 293-304. 
Kumar, V., Rajan, B., Gupta, S., \& Dalla Pozza, I. (2017). Customer engagement in service. Journal of the Academy of Marketing Science, 1-23.

Lam, S. K., Ahearne, M., Mullins, R., Hayati, B., \& Schillewaert, N. (2013). Exploring the dynamics of antecedents to consumer-brand identification with a new brand. Journal of the Academy of Marketing Science, 41(2), 234-252.

Lee, S. A., \& Jeong, M. (2014). Enhancing online brand experiences: An application of congruity theory. International Journal of Hospitality Management, 40, 49-58.

Leckie, C., Nyadzayo, M. W., \& Johnson, L. W. (2016). Antecedents of consumer brand engagement and brand loyalty. Journal of Marketing Management, 32(5-6), 558-578.

Liao, H., \& Chuang, A. (2004). A multilevel investigation of factors influencing employee service performance and customer outcomes. Academy of Management journal, 47(1), 41-58.

Liat, C. B., Mansori, S., \& Huei, C. T. (2014). The associations between service quality, corporate image, customer satisfaction, and loyalty: Evidence from the Malaysian hotel industry. Journal of Hospitality Marketing \& Management, 23(3), 314-326.

Liu, F., Li, J., Mizerski, D., \& Soh, H. (2012). Self-congruity, brand attitude, and brand loyalty: A study on luxury brands. European Journal of Marketing, 46(7/8), 922-937.

Mohsin, A., \& Lockyer, T. (2010). Customer perceptions of service quality in luxury hotels in New Delhi, India: An exploratory study. International Journal of Contemporary Hospitality Management, 22(2), 160-173.

Parasuraman, A., Zeithaml, V. A., \& Berry, L. L. (1988). SERVQUAL: A multiple-item scale for measuring consumer perc. Journal of Retailing, 64(1), 12-40.

Rather, R. A. (2018). Investigating the impact of customer brand identification on hospitality brand loyalty: A social identity perspective. Journal of Hospitality Marketing \& Management, 27(5), 487-513.

Rather, R.A. \& Camilleri, M.A. (2019). The Customers' Brand Identification with Luxury Hotels: A Social Identity Perspective. In Harrison, T. \& Brennan, M. (Eds.) 2019 AMS World Marketing Congress. Edinburgh, Scotland (10-13 July, 2019). Academy of Marketing Science Proceedings.

Rather, R. A. (2019). Consequences of consumer engagement in service marketing: An empirical exploration. Journal of Global Marketing, 32(2), 116-135.

Rather, R. A. \& Hollebeek, L. D. (2019). Exploring and validating social identification and social exchange-based drivers of hospitality customer loyalty', International Journal of Contemporary Hospitality Management, 31(3), 1432-1451. 
Rather, R. A., Hollebeek, L. D., \& Islam, J. U. (2019). Tourism-based customer engagement: The construct, antecedents, and consequences. The Service Industries Journal, 39(7-8), 519-540.

Rauch, D. A., Collins, M. D., Nale, R. D., \& Barr, P. B. (2015). Measuring service quality in midscale hotels. International Journal of Contemporary Hospitality Management, 27(1), 87-106.

Rihova, I., Buhalis, D., Moital, M., \& Gouthro, M. B. (2015). Conceptualising customer-tocustomer value co-creation in tourism. International Journal of Tourism Research, 17(4), 356-36

Romero, J. (2017). Customer engagement behaviors in hospitality: Customer-based antecedents. Journal of Hospitality Marketing \& Management, 26(6), 565-584.

Sirgy, M. J., Lee, D. J., Johar, J. S., \& Tidwell, J. (2008). Effect of self-congruity with sponsorship on brand loyalty. Journal of Business Research, 61(10), 1091-1097.

So, K. K. F., King, C., Sparks, B., \& Wang, Y. (2013). The influence of customer brand identification on hotel brand evaluation and loyalty development. International Journal of Hospitality Management, 34, 31-41.

So, K. K. F., King, C., Sparks, B. A., \& Wang, Y. (2014). The role of customer engagement in building consumer loyalty to tourism brands. Journal of Travel Research, 55(1), 64-78.

So, K. K. F., King, C., Hudson, S., \& Meng, F. (2017). The missing link in building customer brand identification: The role of brand attractiveness. Tourism Management, 59, 640-651.

Su, N., Mariadoss, B. J., \& Reynolds, D. (2015). Friendship on social networking sites: Improving relationships between hotel brands and consumers. International Journal of Hospitality Management, 51, 76-86.

Su, N., \& Reynolds, D. (2017). Effects of brand personality dimensions on consumers' perceived self-image congruity and functional congruity with hotel brands. International Journal of Hospitality Management, 66, 1-12.

Tuškej, U., Golob, U., \& Podnar, K. (2013). The role of consumer-brand identification in building brand relationships. Journal of business research, 66(1), 53-59.

Tuškej, U., \& Podnar, K. (2018). Consumers' identification with corporate brands: Brand prestige, anthropomorphism and engagement in social media. Journal of Product \& Brand Management, 27(1), 3-17.

Vivek, S. D., Beatty, S. E., \& Morgan, R. M. (2012). Customer engagement: exploring customer relationships beyond purchase. Journal of Marketing Theory and Practice, 20(2), 122-146.

Vivek, S. D., Beatty, S. E., Dalela, V., \& Morgan, R. M. (2014). A generalized multidimensional scale for measuring customer engagement. Journal of Marketing Theory and Practice, 22(4), 401-420. 
Zeithaml, V. A., Bolton, R. N., Deighton, J., Keiningham, T. L., Lemon, K. N., \& Petersen, J. A. (2006). Forward-looking focus: can firms have adaptive foresight? Journal of Service Research, 9(2), 168-183.

Zhang, J., \& Bloemer, J. M. (2008). The impact of value congruence on consumer-service brand relationships. Journal of Service Research, 11(2), 161-178.

\section{Note on the Contributors}

Rather Ahmad Raouf is a full time Ph.D. candidate in Marketing Management at the Business School, University of Jammu, India. He holds an MBA in Marketing. He has published his work in highly indexed academic journals. He is the Editorial Coordinator of "Journal of Tourism and Management Research" and also acts as a reviewer of various national and international journals.

Mark Anthony Camilleri is an Associate Professor within the Department of Corporate Communication at the University of Malta. He completed his full-time Ph.D. (Management) at the University of Edinburgh in Scotland - where he was also nominated for his "Excellence in Teaching". He is a scientific expert in research for the Ministero dell' Istruzione, dell' Universita e della Ricerca (in Italy) and an editorial board member in a number of journals. 